\title{
Harassment Act Implementation in Higher Education Institutions
}

\author{
Rizwana Yousaf1, Rudi Schmiede ${ }^{2}$ \\ ${ }^{1}$ Technische Universitaet Darmstadt, Darmstadt, Germany \\ ${ }^{2}$ Prof. Emeritus of Sociology (Work, Technology and Society) at Technische Universitaet Darmstadt, Darmstadt, \\ Germany \\ Email: rizwana.yousaf@stud.tu-darmstadt.de,schmiede@ifs.tu-darmstadt.de
}

Received 27 January 2016; accepted 6 March 2016; published 9 March 2016

Copyright (C) 2016 by authors and Scientific Research Publishing Inc.

This work is licensed under the Creative Commons Attribution International License (CC BY). http://creativecommons.org/licenses/by/4.0/

(c) (i) Open Access

\begin{abstract}
Effective implementation of harassment Act might be inevitable to acquiring gender equality in higher education institutions and diminishing the influence of patriarchal and conservative mind set. This study intended to explore implementation of the harassment Act (2010) in universities. Although Government of Pakistan has enforced harassment Act and Higher Education Commission (HEC) made it mandatory to implement, none of the university in the sample has implemented it. Various incidence of harassment has been reported by study participants and in certain cases, victims are asked to resign the jobs as they refuse or fail to comply with the drives of male colleagues and heads. Lack of state and organizational control leads women to be silent and tolerant of harassment and ultimately, it encourages perpetrator to continue the derogatory behaviour.
\end{abstract}

\section{Keywords}

Harassment Act, Implementation, Higher Education Institution, Women

\section{Introduction}

Vigorous harassment policies have long been suggested as an important means of curbing harassment at work place including higher education institutions. After a decade of new Millennium, harassment at workplace in Pakistan has not been considered a legal issue. In 2010 for the first time in history harassment at work was legalised in the country (Jabbar \& Imran, 2013; Sarwar \& Nauman, 2011) by enforcing Sexual harassment Act (2010), after enforcement the main challenge was the implementation of the Act at various work places as well as higher education institutions. Higher education commission (HEC) of Pakistan has developed detailed policy guidelines for higher education institutions to protect the working women against harassment, discrimination, 
unequal treatment with reference to promotion and other rewards and directed the higher education institutes to implement the policy. HEC makes it clear that Higher Education Institution (HEI) has to assure the right of every member of its constituencies to live, study and work indiscrimination and sexual harassment free environment. Policy guidelines clearly state that universities and HEI recognize the significance of free community as an academic, and it is a fundamental right of the academia to have freedom of expression and association. Universities will have to uphold an environment in which students and teaching and non-teaching staff can engage in free inquiry and open discussion of all issues without intimidation and harassment of others. The HEI required to take measures (by implementing the policy guidelines) to protect all of its members from sexual harassment and to take action if such harassment does occur. Universities were directed to establish an educational program to prevent incidents of sexual harassment. All Administrators, Deans, Managers, Department Chairs, Directors of Schools or Programs and others in Supervisory or Leadership positions have an obligation to be familiar with and to uphold this policy and its procedures and appointing Harassment Monitoring Officer (HMO) along with informing members of their staff about its existence (HEC, 2011).

According to Higher Education Commission (2011) policy guidelines sexual harassment is an everyday reality which occurs in the classrooms, offices, research laboratories, and HEI environment in general (HEC, 2011) in Pakistan. The policy guidelines explained the sexual harassment an overt or subtle, and can range from visual signals or gestures to verbal abuse to physical contact along with hand or sign language to denote sexual activity, sexual compliances are exchanged or proposed to be exchanged for rewards in job or in education, persistent and unwelcome flirting. Sexual harassment, generally takes place in power or authority difference among persons involved (Student/Teacher, Employee/Supervisor, Junior Teacher/Senior Teacher, Research Supervisee/ Supervisor) (HEC, 2011).

Proactive policies might need to be implemented to maintain the imbalanced situation that continues to prevail in the academic sector (Peterson, 2014; Stanford Report, 2014; Subramaniam et al., 2014; Bruckmüller et al., 2014; UCU, 2013; Researchers’ Report Germany, 2013; Catalyst, 2013; Liu, 2013; Catalyst, 2012; European Commission, 2012; Bracken, Allen, \& Dean, 2006). As per the cited literature, it may be recommended that intensive organizational efforts might be required to reduce discrimination, harassment, sex segregation and to employ women and men in various levels of authority, across the organization. According to Bureau of Statistic (2013) women in Pakistan are almost half of the total population and in higher education institutes more than 50\% population comprised of women, in coming years they are going to be further contributing towards work force. So at this stage it is important to provide gender equality and safe working environment for working women so they can play a vital for the progress of the country. By employing more women heads incidents of sexual harassment on the one hand can be reduced and on the other hand it may effetely handle the complaints of SH as well (Equal Employment Opportunity Commission, 2014).

This study, based on the inquiry that the absence of any effective formal control in the form of sexual harassment Act implementation in higher education institutions will not only promote sexual harassment and offensive behaviours rather such behaviours will go further unchecked.

\section{Material and Methods}

This study is the part of the doctoral dissertation, which was based on Triangulation method, i.e. quantitative, qualitative and observational method was employed to investigate the phenomena. The research employed maximum variation in sampling to capture differences among women serving in various hierarchical positions (16 - 21 hierarchical scale) in universities. They were surveyed to measure their level of awareness and to what extent harassment Act has been implemented in their respective university. At the same time it was also made sure to capture the variations in terms of institutional structure like public, private and public-private sector universities in Punjab, Pakistan were randomly selected to capture the variety of all types of institutions. Faculties were selected randomly in each university and in selected faculties all the departments were included in the sample. In the selected departments all the women working from scale 16 - 21 were the part of the sample. Specifically, all of the universities in the sample were categorized general universities. On the first stage, a list of employees was taken from the respective university's website (many universities do not update their websites regularly) so during the data collection phase already developed list was matched with existing faculty and amended if some of the employees had left the institute or were on leave. Those who were working at the time of data collection were included in the sample. 
Total 451 participants were randomly selected and finally 411 questionnaires were collected, some of the respondents had misplaced the questionnaire and they were not intended to take a new one and some of them never found in their office despite repeated visits. The data have been collected in a pen-paper survey.

\subsection{Qualitative Phase: Sampling Strategy}

Criteria of the universe (universities) remained same in the qualitative phase as data has been collected from four universities. According to HEC (2011) policy guidelines, all heads of department, institutes and school need to be familiar with harassment Act and to implement the policy, including appointing Harassment Monitoring Officer (HMO) along with informing members of their staff about its existence HEC (2011). So they were interviewed to measure their familiarity and steps taken for implementation of the harassment Act in their respective department and/or institute.

Confidentiality and privacy were important concerns of this research; therefore the participant's identity and the department's name were converted into pseudo name and identities.

For the privacy concerns, instead of naming the universities they were altered by its type i.e. public, private, and public-private.

There were three primary types of variation of participants:

1) Heads: hierarchical position, head of departments, head of institute, director or dean (to check familiarity and implementation).

2) University type (public, private, public-private).

3) University size (small, large)

\subsection{Sample Method}

To find participants, firstly, through the websites of university participants was identified and secondly an invitation email to participate in the study was sent. In the first phase about 30 Head of Departments’ Deans and Directors were contacted, unfortunately, except two participants none of the others has replied to email. Afterwards researcher went to Pakistan and personally visited their offices and gets the appointment and then conducted the interview. Some of the heads were so cooperative that they asked to wait for some time and they get their meeting or assignment done and they gave interviews straight away. Interviews were conducted in a very friendly environment and some of the participants offered the cup of tea.

Sample size was an important consideration for this qualitative research design. Lincoln \& Guba (1985) recommend sample selection for qualitative research to the point of redundancy, when new participants yield no new information (Diehl, 2013). According to (Mason, 2010), this point of saturation can be difficult to identify. Although many researchers claim to get saturation without proving it, as new data will always add something new to a study, but after a certain point, there are diminishing returns (Mason, 2010). In the present research 13 interviews were conducted as the purpose of the interviews was to find out primarily the implementation of the harassment Act in their respective university. Presented research's point was saturation, interviews continued until new interview yielding limited information.

The second phase of interviews was the coding phase. To code data, firstly I transcribe all 13 interviews and compile my field notes. Consequently, I highlighted all the areas which were corresponding to my research questions. I read through my interview transcripts, and field notes, highlighting and annotating all areas which spoke to my research question. I then collected all the annotations and organized them with labels which corresponded to themes (Diehl, 2013).

After finalizing the themes I look for the internal homogeneity and external heterogeneity so the themes produce the coherent and meaningful analysis. Homogeneity was sure to make themes which were mutually exclusive and external homogeneity was ensured that themes were not overlapping in various sections (Mayring, 2000).

I had gone through a logical analysis across the themes to explore their interconnectedness (Patton, 2002). Similarly (Patton, 2002) has highlighted the importance of interpretive analysis by describing interpretation goes beyond the descriptive data by attaching significance to what was found, finding meanings, offering explanations, and drawing conclusions. I used the data (interviews, field notes, and generated themes), social perspective and my own perspective and understandings make sense of the evidence (Patton, 2002). Both the evidence and my perspective are elucidated so that the difference between the description of the data and my interpreta- 
tion is clear (Patton, 2002).

\section{Findings and Discussion}

In a quantitative stage substantial number of respondents (44.5\%) was having a Masters of Philosophy/Masters of Science (M. Phil/MS) degrees. Simultaneously 33.8\% of the participants were having Masters Degrees (equivalent to Bachelors). Whereas only $14.8 \%$ respondents have done doctoral degrees. Significant majority having varying work experience ranging from 1 - 10 years, and $61.1 \%$ respondents were married and $67.9 \%$ were living either in joint or extended families.

The findings of the current survey showed that significant majority $51.3 \%$ of the participants were working as a Lecturer, which is lowest scale in the academic hierarchy, 22.4\% of the participants were working as Assistant Professor and $5.8 \%$ of the participants were working as Associate Professor and there were only $4.6 \%$ women Professors, which clearly shows that most of the women were working on low academic hierarchy. As far as the data for women working in administrative departments was concerned, most of the women working on the Registration and Administration offices and the majority of them were working as office Assistants or Administrative Assistants and predominantly were doing clerical jobs. The highest hierarchal level of women working in administration in presenting study was Assistant Director and their organizational scale or positions are mostly lower than the Lecturers.

Many of Pakistani women knew that the workplace can be a predatory arena, where the right to public space is seen as a male privilege-which is why the protection against 'Harassment of Women at the Workplace Act (2010)' was a much-needed piece of legislation in the country. This Act first time recognized the legal status of sexual harassment in the country (Jabbar \& Imran, 2013; Sarwar \& Nauman, 2011). This came at the time when the concerned public was becoming increasingly aware of the seriousness of the problem (Jabbar \& Imran, 2013). A pen-paper survey was used to measure the extent to which the concerned public is aware of this Act and simultaneously to what extent higher education institutions have already implemented the Act. Firstly, it asked the participants if they have knowledge about sexual harassment Act 2010, in response to this question, $49.1 \%$ of the participants knew about the Act, whereas slightly more than half of the participants $50.9 \%$ did not know about the act. These findings are very significant that all the participants of the study were highly educated and they were working in universities. Somehow half of the highly educated population did not know about the Act, which was actually formulated for their protection. Similarly, in near past another study in the biggest city of Pakistan i.e. Karachi has also been conducted in educational institutions to find out the awareness level of the working women about sexual harassment Act (2010), the study found out many of educated and employed women were unaware of the rights and privileges of the Act (Sadruddin, 2013). At the same time Higher Education Commission of Pakistan (HEC) also found that the Act (2010) has been enforced, but it is yet to be implemented by a majority of the workplaces and Higher Education Institutions in Pakistan (HEC 2013). It might be interesting to explore the awareness level of women working in other sector where they might not be as highly educated as the current study's participants, although it was also found out those who were working in unorganized sector, they were primarily uneducated were completely unaware of such Act and their rights and privileges (Yousaf \& Qadir, 2014).

While half of the participants did not know about the Act, those who knew about the Act, it was further probed from them and $29.7 \%$ of the participant got information of Act from parent university, $27.2 \%$ of the participant acquired some sort of information from other university, at the same time print and electronic media has also played the role in informing the participants and 21.3\% caught information from TV, and $21.8 \%$ of the participants read some news or advertisements from daily Newspapers.

However, it was obligatory by the Government of Pakistan and HCE for Universities to implement the Act (HEC, 2011). So it was asked if the Act had already been implemented in a department and $17.3 \%$ of the participants said it is implemented and $82.7 \%$ said the Act is not implemented in their respective universities.

Although $82.7 \%$ of the study participants said the Act was not implemented in their respective departments, but in order to make sure, that it might be possible that certain other requirements of the Act might have been adopted by the universities. So it was further asked if the Act has been displayed in their university or department, on response to this question, $8.8 \%$ said yes, and $91.2 \%$ said it was not displayed. Those $8.8 \%$ have told that it is displayed in the department. They were further questioned on second visit to get the clarification of their response. While researching, researcher had visited departments to check if the Act was displayed, but it could not be found, I talked to some of the participants to assure that where they have seen that displayed Act, 
and some of the participants said that they have seen the displayed Act in some other Governmental Institutes but not in their corresponding university.

Although $91.2 \%$ of the participants said that the Act is not displayed in their University, but it was asking them if they have the copy of the Act in their offices, so that they can read the clauses, but $17.0 \%$ of the participants had the copy whereas $83.0 \%$ participants did not have the copy of the Act in their offices.

One of the core clauses of the sexual harassment Act required relevant institute or the university to organize seminars for awareness (Gillani, 2010; HEC, 2011), so when it was asked if their department or university has organized a seminar $22.4 \%$ of the participants said that the seminar has been organized whereas $77.6 \%$ said no seminar has been organized.

One of the clauses of the Act stated that departments and institutes are advised to constitute a committee to deal with SH cases (Gillani, 2010; HEC, 2011), so it was asked if there department has constituted the committee $29.4 \%$ of the participants told there department has formulated the committee whereas $70.6 \%$ said there was no such committee. For clarifications it was discussed in detail with some of the participants about the formulation of the committee. I learnt that almost all the departments have constituted the disciplinary committees, which deals with the complaint of departments in general, specifically for students and occasionally for the teachers. So the participants have confused the disciplinary committee with the committee, which meant to deal with the sexual harassment cases. Although departments had disciplinary committee, so it asked the participants, have they ever or any of her colleagues had registered the complaint to such committee and $25.3 \%$ of the participants said that complaints have been registered whereas, $74.7 \%$ of the participants have told neither they nor any colleague had ever registered complain.

It was asked to the participants those who had ever filed the complaint were they satisfied with the handling of their cases and $40.1 \%$ of the participants were satisfied with handling of sexual harassment cases whereas $59.9 \%$ of the participants were not satisfied.

Sexual harassment at workplace is a leading form of gender based inequality which working women are facing (Thomas, 2015; Naz et al., 2013). Still, generations of women remained silent and reluctant to lodge formal or informal complaints against sexual harassment experiences at the workplace because of the fear of job, shame, stigmatization on women's reputation and many do not want their families to know about their issues (Khan, Begum, \& Shaheen 2015; D’Cruz \& Rayner, 2013).

There have been Laws in world for some good time to protect the women at work place like sexual harassment Law of Brazil, Belize, Philippines and Israel, Equality and sex discrimination Laws of Japan and South Africa, National Human Right Legislation Fiji and New Zealand, Laws on safe working conditions of Netherlands (EEOC, 2006) and Pakistan too opted some five years ago by enforcing protection against harassment of women at the Workplace Act, 2010 (Jabbar \& Imran, 2013; Gillni, 2010). These prohibitions provide criminal and/or individual penalties for such discriminatory and harassing behaviour (Gillni, 2010). Nonetheless, despite bans against sex discrimination, in most countries, as in Pakistan, women's lower earnings, status, sufferings and under representation at the upper echelons of the hierarchy when compared with men's provide evidence of gender inequality and discrimination continued its existence (Hejase, 2015; McDonald, Charlesworth, \& Graham, 2015). It was mandatory for all organizations and universities in Pakistan to implement the protection against harassment of women at the workplace Act (2010) but till 2013, more than 80\% Universities of Pakistan had not implemented the Law (HEC 2013).

So in order to check the implementation of the Act and knowledge of study participants, following research question and hypothesis has developed:

What is the percentage of women having knowledge about the sexual harassment Act (2010) and percentage of Act implemented in public large, public small, public-private and private Universities in Pakistan in 2014?

\subsection{Research Hypothesis}

Ha: Does difference exist in the percentage of women having knowledge about Sexual Harassment Act (2010) and the percentage of implementation of the Act between or among the percentage of public large, public small, public private and private universities in Pakistan in 2014.

\subsection{Quantitative Analysis}

Multivariate test results are statistically significant and it (Table 1) shows that the difference did exist in the 
percentage of women having knowledge about the sexual harassment Act (2010) and the implementation of the Act and between or among the percentage of public large, public small, public private and private universities in Pakistan in 2014. So the Null hypothesis is rejected.

For further clarification, Tests of Between-Subjects Effects is performed.

If we look at the Tests of Between-Subjects Effects it (Table 2) shows that there is statistically significant difference exist in the percentage of women having knowledge about Sexual Harassment Act (2010) and between or among the percentage of public large, public small, public-private and private universities in Pakistan in 2014.

Table 1. Multivariate tests ${ }^{\mathrm{c}}$ of varaince.

\begin{tabular}{|c|c|c|c|c|c|c|c|}
\hline & Effect & Value & $\mathrm{F}$ & Hypothesis df & Error df & Sig. & Partial Eta Squared \\
\hline \multirow{4}{*}{ Intercept } & Pillai’s Trace & .954 & $4.178 \mathrm{E}^{\mathrm{a}}$ & 2.000 & 406.000 & .000 & .954 \\
\hline & Wilks’ Lambda & .046 & $4.178 \mathrm{E}^{\mathrm{a}}$ & 2.000 & 406.000 & .000 & .954 \\
\hline & Hotelling’s Trace & 20.582 & $4.178 \mathrm{E}^{\mathrm{a}}$ & 2.000 & 406.000 & .000 & .954 \\
\hline & Roy’s Largest Root & 20.582 & $4.178 \mathrm{E}^{\mathrm{a}}$ & 2.000 & 406.000 & .000 & .954 \\
\hline \multirow{4}{*}{ Q.1 } & Pillai’s Trace & .049 & 3.431 & 6.000 & 814.000 & .002 & .025 \\
\hline & Wilks' Lambda & .951 & $3.455^{\mathrm{a}}$ & 6.000 & 812.000 & .002 & .025 \\
\hline & Hotelling’s Trace & .052 & 3.480 & 6.000 & 810.000 & .002 & .025 \\
\hline & Roy's Largest Root & .048 & $6.525^{\mathrm{b}}$ & 3.000 & 407.000 & .000 & .046 \\
\hline
\end{tabular}

${ }^{\text {a }}$. Exact statistic; ${ }^{\mathrm{b}}$. The statistic is an upper bound on F that yields a lower bound on the significance level; ${ }^{\mathrm{c}}$. Design: Intercept + Q.1.

Table 2. Tests of between-subjects effects.

\begin{tabular}{|c|c|c|c|c|c|c|c|}
\hline Source & Dependent Variable & Type III Sum of Squares & df & Mean Square & $\mathrm{F}$ & Sig. & Partial Eta Squared \\
\hline \multirow{2}{*}{$\begin{array}{c}\text { Corrected } \\
\text { Model }\end{array}$} & Knowledge about SH Act (2010) & $4.711^{\mathrm{a}}$ & 3 & 1.570 & 6.522 & .000 & .046 \\
\hline & Act Implemented & $.226^{\mathrm{b}}$ & 3 & .075 & .530 & 662 & .004 \\
\hline \multirow{2}{*}{ Intercept } & Knowledge about SH Act (2010) & 676.839 & 1 & 676.839 & $2.811 \mathrm{E} 3$ & .000 & .874 \\
\hline & Act Implemented & 922.047 & 1 & 922.047 & $6.487 \mathrm{E} 3$ & .000 & .941 \\
\hline \multirow{2}{*}{ Q.1 } & Knowledge about SH Act (2010) & 4.711 & 3 & 1.570 & 6.522 & .000 & .046 \\
\hline & Act Implemented & .226 & 3 & .075 & .530 & .662 & .004 \\
\hline \multirow[b]{2}{*}{ Error } & Knowledge about SH Act (2010) & 98.009 & 407 & .241 & & & \\
\hline & Act Implemented & 57.852 & 407 & .142 & & & \\
\hline \multirow[b]{2}{*}{ Total } & Knowledge about SH Act (2010) & 1038.000 & 411 & & & & \\
\hline & Act Implemented & 1434.000 & 411 & & & & \\
\hline \multirow{2}{*}{ Corrected Total } & Knowledge about SH Act (2010) & 102.720 & 410 & & & & \\
\hline & Act Implemented & 58.078 & 410 & & & & \\
\hline
\end{tabular}

\footnotetext{
${ }^{\mathrm{a}}$. $\mathrm{R}$ Squared $=.046$ (Adjusted R Squared $\left.=.039\right){ }^{\mathrm{b}}$. $\mathrm{R}$ Squared $=.004$ (Adjusted R Squared $\left.=-.003\right)$.
} 
Whereas there was no statistically significant difference exist between or among the percentage of public large, public small, public-private and private universities in Pakistan in 2014 in the implementation of the sexual harassment Act (2010). It also indicated that universities in the sample had not implemented the act till August 2014.

As the multivariate results are statistically significant, then it is important to see the Post Hoc test.

For in depth comparison of various universities, if we look at the Post Hoc test, and we came to know that small public university did differ with all other universities in terms of knowledge of the sexual harassment Act and vice versa. It is evident from the post Hoc test that women employed in small public university have more knowledge about the harassment Act (2010) or their awareness about the Act was higher than the rest of women employed in other universities of the sample. It could be assumed that small university has more conducive and less anonymous environment which might have role for better awareness. Hence, in terms of the implementation workplace Act (2010) all the universities in the sample did not statistically significantly differ as none of them has implemented the Act (Table 3).

Table 3. Post Hoc test for difference between type of university.

\begin{tabular}{|c|c|c|c|c|c|c|c|}
\hline \multicolumn{8}{|l|}{ Turkey HSD } \\
\hline \multirow{2}{*}{$\begin{array}{l}\text { Dependent } \\
\text { Variable }\end{array}$} & \multirow{2}{*}{$\begin{array}{l}\text { (I) Type of } \\
\text { the University }\end{array}$} & \multirow{2}{*}{$\begin{array}{l}\text { (J) Name of } \\
\text { the University }\end{array}$} & \multirow{2}{*}{$\begin{array}{l}\text { Mean Difference } \\
\text { (I-J) }\end{array}$} & \multirow{2}{*}{$\begin{array}{l}\text { Std. } \\
\text { Error }\end{array}$} & \multirow{2}{*}{ Sig. } & \multicolumn{2}{|c|}{ 95\% Confidence Interval } \\
\hline & & & & & & Lower Bound & Upper Bound \\
\hline \multirow{12}{*}{$\begin{array}{c}\text { Do you have } \\
\text { knowledge about } \\
\text { Sexual Harassment } \\
\text { Act } 2010\end{array}$} & \multirow{3}{*}{ Large Public } & Public-Private & -.10 & .062 & .393 & -.26 & .06 \\
\hline & & Private & .03 & .063 & .976 & -.14 & .19 \\
\hline & & Small Public & $-.38^{*}$ & .093 & .000 & -.62 & -.14 \\
\hline & \multirow{3}{*}{ Public-Private } & Large Public & .10 & .062 & .393 & -.06 & .26 \\
\hline & & Private & .12 & .074 & .335 & -.07 & .31 \\
\hline & & Small Public & $-.28^{*}$ & .101 & .027 & -.54 & -.02 \\
\hline & \multirow{3}{*}{ Private } & Large Public & -.03 & .063 & .976 & -.19 & .14 \\
\hline & & Public-private & -.12 & .074 & .335 & -.31 & .07 \\
\hline & & Small Public & $-.41^{*}$ & .101 & .000 & -.67 & -.15 \\
\hline & \multirow{3}{*}{ Small Public } & Large Public & $.38^{*}$ & .093 & .000 & .14 & .62 \\
\hline & & Public-Private & $.28^{*}$ & .101 & .027 & .02 & .54 \\
\hline & & Private & $.41^{*}$ & .101 & .000 & .15 & .67 \\
\hline \multirow{12}{*}{$\begin{array}{l}\text { Does the Act } \\
\text { implemented in } \\
\text { your department }\end{array}$} & \multirow{3}{*}{ Large Public } & Public-Private & -.05 & .048 & .705 & -.17 & .07 \\
\hline & & Private & -.04 & .048 & .793 & -.17 & .08 \\
\hline & & Small Public & -.04 & .072 & .953 & -.22 & .15 \\
\hline & \multirow{3}{*}{ Public-Private } & Large Public & .05 & .048 & .705 & -.07 & .17 \\
\hline & & Private & .01 & .057 & .999 & -.14 & .15 \\
\hline & & Small Public & .01 & .077 & .998 & -.19 & .21 \\
\hline & \multirow{3}{*}{ Private } & Large Public & .04 & .048 & .793 & -.08 & .17 \\
\hline & & Public-Private & .00 & .057 & .999 & -.15 & .14 \\
\hline & & Small Public & .01 & .078 & 1.000 & -.19 & .21 \\
\hline & \multirow{3}{*}{ Small Public } & Large Public & .04 & .072 & .953 & -.15 & .22 \\
\hline & & Public-Private & -.01 & .077 & .998 & -.21 & .19 \\
\hline & & Small Public & .00 & .078 & 1.000 & -.21 & .19 \\
\hline \multicolumn{8}{|c|}{$\begin{array}{l}\text { Based on observed means. } \\
\text { The error term is Mean Square (Error) = .142. }\end{array}$} \\
\hline The mean difference is & at at the .05 le & & & & & & \\
\hline
\end{tabular}




\subsection{Qualitative Analysis}

Head of Department, Dean, Director and Head of the institute are liable to HEC to be familiar and implement the harassment Act (2010) in their respective department and institute. Firstly, it was important to ask them if they knew about the work place Act and secondly, it was explored if the Act has been implemented in their department or institutes. In this study there were 6 female and 7 male heads interviewed, except one female and 3 male heads none of others knew about the harassment Act (2010). When a participant is unaware of the Act itself, it left the limited room to further explore for implementation of the Act. The analysis of interviews will be described as follows:

\subsection{Lack of Knowledge about Law}

In this study there were thirteen interviewed conducted from large public, small public, public-private and private university, except one female and 3 male heads none of others knew about Harassment Act (2010). Some of them requested researcher if the Act could be explained to them, they might comment on it, when it was explained; they said we have not heard about it. Though recently in print and electronic media there were some advertisements to guide and aware the women regarding their workplace rights and harassment Act.

Interestingly a female Head said:

If the law is enforced, "I am sure it must be implemented in University" (Ager Law buna huva hai to yaqeenana lago huva hog a).

Another female Head explained:

In our society harassment is a derogatory term, the majority got offended about the term. But it is very important to understand what harassment is. But I have not read the harassments Act (2010) yet.

\subsection{Disciplinary Committee}

Although the majority of the participants were unaware of harassment Act, it was asking for them, if they have constituted a committee and appointed and HMO to deal with complaints by students and staff. In response to the questions, almost all the participants discussed that there are disciplinary committees in their departments which deal with complaints regarding any inappropriate behaviours. There were some staff members responsible to handle the committee matters. But specifically, there was no such committee who deals explicitly with sexual harassment complaints. These disciplinary committees usually dealt with student's misconduct or complaints.

A male head told:

Such committee are not very useful in our society as women are reluctant to lodge any formal complaints, even if they are facing harassment in their department or university.

He further added:

Informal grievance procedures for sexual harassment complaints may be more successful than formal ones in Pakistani cultural context where due to the traditional aspects of society women's distress to discuss such an issue with male members. In addition, rather than punishment or retribution, many harassed women simply want the behaviour to stop. This suggests that in addition to formal grievance policies, organizations could include informal dispute resolutions that focus on harassment cessation for harassment targets they would be more contented with such measures. The presences of women in authority positions might better deal with harassment complaints, firstly complainant would be more convenient to discuss with women's head and secondly, women heads could use their positions of influence to increase gender equality and reduce sexual harassment (Brink, Benschop, \& Brouns, 2010).

\subsection{Committees Constituted, Law Displayed, Organized Seminar}

Interviews have been conducted in public large, small, public-private and private universities and there was only one female head, who thoroughly knew about the harassment Act (2010).

She explained:

We have organized a seminar in our department. It was mandatory for students and faculty to attend it. Through seminar I actually came to know what the Law is? How it works? How it could be implemented? I thoroughly understood the Law by arranging and attending the seminar.

She further explained: 
Even after the seminar I understood what harassment is? I always used to think harassment is only a physical encounter, and then I came to know even gaze or verbal expressions could be categorized as harassment. This is quite common in our setup.

She added: the Law is very significant for women, and every working woman should read and understand it, if a woman herself is not interested to know about her work right, then no one will bother to give her rights.

She also told: After the seminar we displayed the Law in our department, though I try to find the place, but I could not, where actually the law was displayed.

\subsection{Act Not Implemented}

A male head satirically asked, have you ever seen or heard that such Laws have ever been implemented in our society in general or in any university specifically?

He further added:

I suppose all the women at work place, parliament and on the streets in Pakistan should be protected, but you can see, this is not the case. If the Laws in Pakistan could have been implemented, the situation of our society would have been different. Those who have made the Laws they themselves violated them. Parliament has passed the Law but women sitting in parliament are victims of harassment.

Very thoughtfully he told:

It was formality to constitute a committee for so called implementation of this Law and we have made it sure the formality is there...

Another male head with 27 years' experience told:

I have not seen or heard, if the law is implemented in my university. We had two female Assistant Professors who were victims of harassment. We came to know about the incident, when victims were asked to resign their job. As the boss was not happy with refusal...

He further added:

I think, even if this Law is implemented in universities, we cannot control the harassment of women, as everywhere men harass them, and if a woman is working with males and she says I never experienced harassment, I am not going to believe it as it is not possible to escape harassment in Pakistani society.

He also narrated:

But they don't report such incidence as the privacy of the victim is subject to scrutiny, and harassers identity has to be revealed too, if there is zero tolerance for harassment in society, still there will be harassed, it is not necessary that women face harassment from her boss rather she could receive harassment from male working on lower grade.

A female Head said:

In my university there has been a male from clerical staff he took cell number of all female employees and he used to send us obscene messages, which was very disturbing that you open your phone and you see sexually explicit horrible material which really disturbs you. Although he was traced later and I think he is not in university now.

She further elaborated, If this Law is already enforced, there is need to implement it in true spirit. She further explained:

Awareness cannot be given by organizing seminars in universities. Who does not know harassment in this society? If we arrange a seminar in university, she asked, who will attend the seminar? "Either victims or the harassers". Women can only be protected if the harassers know there are severe punishments otherwise making of such Law is simply the wastage of time.

Other female head said there was a harassment case in my department; male head (who was serving at the time of the incident) might be involved. I don't know the details exactly, he is already retired, and secondly, I was not serving as a head that time. She was reluctant to discuss the issue.

Another female Head said:

Have you ever heard somebody got punishment due to the law, if the law is not implemented it is useless, A Law without implementation is merely a piece of paper. If there were punishments, the culprits would have thought a hundred times before committing such acts.

Satirically she narrated; women have been harassed at workplace on the street and in public transports before and after 2010. You could well imagine how good the implementation is? 
She further explained:

The Majority of my colleagues is male, though I never experienced harassment in my department, but the situation is not same in all departments, I know women face harassment in other departments. I have neither organized a seminar, nor displayed it in my department. We actually do not need it as an environment in my department is safe and good.

A Male head told:

I don't think so, that in my university we have implemented or displayed the Law, but I read harassment Act last month by chance, I visited a Government institute, and it was displayed in their entrance lobby. I read the whole Law, that sound interesting. I think all the departments should display the Law, where students and faculty can easily read, it is very important for everyone to know what actually the Law is.

A male Head told:

I don't know about the Law. But we don't need any Law here, as Islam has already given us a Law to respect the women. He further explained, but I know women face hype of harassment in our society. But I am bound to believe that they are not experiencing any such problem because they are not reporting it, if somebody is not speaking or reporting. I am supposed to consider everything is ok for women.

Another male Head said:

Though I have not read the Law yet, but as far as the harassment of women a concern in my opinion it cannot be controlled in our society. Because male will keep on harassing the women and women have no other option but to tolerate if they wanted to come out of their house. Hence, many of them never dare to report, due to the fear and stigma. If she belongs to upper economic strata of society, she might file a case, otherwise middle class woman prefer to stay quiet, earning is more important for them and they could not ruin their struggle to get university employment by merely reporting a harassment which somehow unavoidable in our society.

Another female Head explained:

Many women are facing harassment at work place, and men do it just to suppress the women. Nearly a decade ago women were not very confident, but now the situation is changing. May be in future situation will not be same.

\section{Discussion}

Despite large damage awards discussed by study participants and also by media, most women who are harassed do not file lawsuits or even formally complain (Human Rights Report, 2013; McDonald et al., 2015). Women's failure to complain reflects gender bias in policies, stemming from perceptual differences in the way women and men view harassment and from women's belief that their complaints will not be taken seriously and they would stigmatise themselves, which stem from ineffective mechanisms to deal with such cases and lack of implementation of harassments Act. Historically women in Pakistan were not encouraged to get higher education, whereas in the last two decades, large proportion of women population not only started getting higher education rather them motivated to come into the job market. Still, the vast majority of the population is uneducated, though with changing economic pressures somehow people stared accepting the women working status, but patriarchal holds and pressures could be seen in various other forms of control on women's freedom and independence. Social conservatism and patriarchal control has been an extensive influence on the women's status in the society. According to Moghadam (1992) patriarchy persists in areas of limited industrialisation, urbanisation and proletarianization, and may be legislated by the state. At the same time, the collision of tradition and modernity and unwanted changes, particularly on the status of women, may result in a preoccupation with cultural identity on the part of some social groups (Moghadam 1992). Participants of the study expressed that patriarchy and social conservatism of the society has been a barrier for women in labour market since long.

\section{Conclusion}

Effective Implementation of harassment Act might be a way to acquiring gender equality at work and diminishing the patriarchal and conservative mind set. Harassment is defined as persistent negative actions by one or several persons towards an individual or a group of people, who have difficulties in defending themselves (Hecker, 2007). Male co-workers, clients, and supervisors might use harassment as an "equalizer" against women in power, consistent with research showing that sexual harassment is less about sexual desire than about control and domination (Hecker, 2007). Various incidence of harassment has been reported by heads of departments and 
institutes and some of cases in academia have been reported my media and in certain cases, victims were asked to resign the jobs as they refuse to comply with the drives of male heads and bosses. Although Government of Pakistan has enforced harassment Act (2010) and HEC made it mandatory, but none of the university in the sample has implemented it till 2014. Even Until 2016 some of the least gender sensitive provinces of Pakistan have not formally enforced and passed the harassment Act, which shows not only non-sensitivity towards the harassment of women rather insignificant concern. In present circumstances, many of discriminations and derogatory acts do not only go unchecked, but it promotes the perpetrators to be more consistent and daring as there are no formal controls. Lack of state and organizational control leads women to be silent, while they have to face consequences of reporting in the form of stigmatization or publicity and/or by losing a job.

\section{References}

Bracken, S., Allen, J., \& Dean, D. (2006).The Balancing Act: Gendered Perspectives in Faculty Roles and Work Lives. Sterling, VA: Stylus.

Brink, V., Benschop, Y., \& Jansen, W. (2010). Transparency in Academic Recruitment: A Problematic Tool for Gender Equality. http://www.Academia.edu

Bruckmüller, S., Ryan, M. K., Rink, F., \& Haslam, S. A. (2014). Beyond the Glass Ceiling: The Glass Cliff and Its Lessons for Organizational Policy. Social Issues and Policy Review, 8, 202-232. http://dx.doi.org/10.1111/sipr.12006

Catalyst (2012). Women in US Management. http://www.catalyst.org/

Catalyst (2013). Catalyst Research; Catalyst Historical List of Women CEO’s of the Fortune Lists: 1972-2013. http://www.catalyst.org/knowledge/fortune-500-ceopositions-held-women

D’Cruz, P., \& Rayner, C. (2013). Bullying in the Indian Workplace: A Study of the ITES-BPO Sector. Economic and Industrial Democracy, 34, 597-619. http://dx.doi.org/10.1177/0143831X12452672

Diehl, A. B. (2013). Making Meaning of Adversity: Experiences of Women Leaders in Higher Education. A Dissertation Submitted to the School of Graduate Studies and Research in Partial Fulfilment of the Requirements for the Degree Doctor of Philosophy: Indiana University of Pennsylvania

Equal Employment Opportunity Commission (2006). Sexual Harassment Charges EEOC \& FEPAs Combined: FY 1992-FY 2000. http://www.eeoc.gov/stats/harass.html

Equal Employment Opportunities Commission (2014). An Annual Report on EEOC Charges, Litigation, Regulatory Developments and Noteworthy Case Developments-FISCAL YEAR 2013. The Littler Report.

http://www.littler.com/files/press/pdf/Annual\%20Report\%20on\%20EEOC\%20Developments\%20-\%20FY\%202013.pdf

European Commission (2012). She Figures. Statistics and Indicators on Gender Equality in Science. Luxembourg: Office for Official Publications of the European Communities

Gillani, Y. R. (2010). The Protection against Harassment of Women at the Workplace Act.

Government of Pakistan, Statistics Division, Pakistan Bureau of Statistics (2013). Pakistan Employment Trends. http://www.pbs.gov.pk/sites/default/files/Labour\%20Force/publications/Pakistan_Employment_2013.pdf

HEC (2011). Policy Guidelines against Sexual Harassment in Institutions of Higher Learning. http://www.hec.gov.pk/MediaPublication/News/Documents/Large\%20Book.pdf

Hejase, H. J. (2015). Sexual Harassment in the Workplace: An Exploratory Study from Lebanon. Journal of Management Research, 7, 107-121.

Jabbar, A., \& Imran, A. (2013). Perception of Glass Ceiling in the Educational Institution: An Evidence from Pakistan. World Applied Sciences Journal, 23, 628-634.

Khan, N., Begum, S., \& Shaheen, A. (2015). Sexual Harassment against Staff and Student Nurses in Tertiary Care Hospitals Peshawar KP Pakistan. International Journal of Innovative Research and Development, 4, 285-292.

Lincoln,Y. S., \& Guba, E. G. (1985). Naturalistic Inquiry. Beverly Hills, CA: Sage.

Liu, S. (2013). A Few Good Women at the Top: The China Case. Business Horizons, 56, 483-490. http://dx.doi.org/10.1016/j.bushor.2013.04.002

Mason, M. (2010). Sample Size and Saturation in PhD Studies Using Qualitative Interviews. Forum Qualitative Sozialforschung/Forum: Qualitative Social Research, 11, Article No.: 8.

Mayring, P. (2000). Qualitative Content Analysis. Forum: Qualitative Social Research, 1, Article No. 20. http://217.160.35.246/fqs-texte/2-00/2-00mayring-e.pdf

McDonald, P., Charlesworth, S., \& Graham, T. (2015). Developing a Framework of Effective Prevention and Response Strategies in Workplace Sexual Harassment. Asia Pacific Journal of Human Resources, 53, 41-58. 
http://dx.doi.org/10.1111/1744-7941.12046

Moghadam, V. M. (1992). Patriarchy and the Politics of Gender in Modernising Societies: Iran, Pakistan and Afghanistan. International Sociology, 7, 35-53. http://dx.doi.org/10.1177/026858092007001002

Naz, A. M. H., Daraz, U., Khan, W., Khan, T., Salman, M., \& Muhamma, D. (2013). A Paradigm Shift in Women’s Movement and Gender Reforms in Pakistan (A Historical Overview). Global Journal of Human-Social Science Research, 13, 20-26.

Human Rights Report (2013). Pakistan 2013 Human Rights Report. http://www.state.gov/documents/organization/220614.pdf

Patton, M. Q. (2002). Two Decades of Developments in Qualitative Inquiry a Personal, Experiential Perspective. Qualitative Social Work, 1, 261-283. http://dx.doi.org/10.1177/1473325002001003636

Peterson, H. (2014). An Academic “Glass Cliff”? Exploring the Increase of Women in Swedish Higher Education Management. Athens Journal of Education, 1, 33-44.

Researchers’ Report Germany (2013). Country Profile: Germany (pp. 2-22). New York: Deloitte.

Sadruddin, M. M. (2013). Sexual Harassment at Workplace in Pakistan-Issues and Remedies about the Global Issue at Managerial Sector. Journal of Managerial Sciences, 7, 113-125.

Sarwar, F., \& Nauman, B. (2011). Antecedents and Experience of Sexual Harassment at Individual and Group Level. 3rd SAICON International Conference on Management, Business Ethics and Economics, Lahore, 28-29 December 2011.

Stanford Report (2014). Women Less Represented in Faculty, Staff Leadership Ranks. http://news.stanford.edu/news/2014/march/facsen-faculty-report-030614.html

Subramaniam, I. D., Arumugam, T., \& Abu Baker Akeel, A. B. A. (2014). Demographic and Family Related Barriers on Women Managers' Career Development. Asian Social Science, 10, 86-94.

Thomas, A. (2015). Incidents of Sexual Harassment at Educational Institutions in India: Preventive Measures and Grievance Handling. International Journal of Recent Advances in Multidisciplinary Research, 2, 317-322.

UCU (2013). Gender Survey of UK Professoriate. http://www.timeshighereducation.co.uk/news/gender-survey-of-uk-professoriate-2013/2004766.article

Yousaf, R., \& Qadir, M. (2014). Sexual Harassment among Women Working in Unorganized Sector (pp. 49-54). Contemporary Social Science. 